\title{
MODEL GOSPODARKI BIMODALNEJ JOHNA K. GALBRAITHA W KONTEKŚCIE KEYNESOWSKIEJ WIZJI FUNKCJONOWANIA GOSPODARKI RYNKOWEJ
}

\section{WSTEP}

Już w latach trzydziestych XX w. John Kenneth Galbraith zajmował się teorią oligopolu i konsekwencjami silnego zmonopolizowania rynku. W swoim wczesnym artykule Monopoly Power and Price Rigidities ${ }^{1}$ Galbraith utrzymywał, że wysoki stopień monopolizacji danej branży jest z teoretycznego punktu widzenia elementem koniecznym do wyjaśnienia sztywności cen podczas Wielkiego Kryzysu. Dalsze elementy koncepcji Galbraitha, takie jak wewnętrzna struktura przedsiębiorstwa, motywacje kierujące jego kierownictwem i cele przez nie realizowane, zostały sformułowane później.

Kiedy w drugiej połowie lat osiemdziesiątych XX w. coraz odważniej wracano do rozpatrywania gospodarki w sposób keynesowski, za główny problem badawczy uznano poszukiwanie adekwatnych do keynesowskiej makroekonomii podstaw mikroekonomicznych. Istotnym zagadnieniem w ramach tych poszukiwań było udzielenie odpowiedzi na pytanie, skąd w gospodarce sztywności cen i płac. Jaki mogą mieć one wpływ na całą gospodarkę? Jak wytłumaczyć niektóre zachowania przedsiębiorstw, które zgodnie z neoklasycznym modelem firmy nie powinny mieć miejsca? Wydaje się, że Galbraith udziela odpowiedzi na te pytania, a jego koncepcja przedsiębiorstwa oraz gospodarki wpisuje się w poszukiwania keynesistów prowadzone w latach osiemdziesiątych XX w.

Celem niniejszego artykułu jest przedstawienie koncepcji Galbraitha w kontekście ekonomii keynesowskiej. Szczególny nacisk położony został na koncepcję przedsiębiorstwa Galbraitha i na jej konsekwencje dla funkcjonowania mechanizmu rynkowego. By ten cel osiągnąc, konieczne jest zaprezentowanie tej koncepcji, począwszy od poglądów Galbraitha na przedsiębiorstwo właśnie, na kluczową rolę technologii w rozwoju firmy oraz na wynikające z tego konsekwencje dla całego systemu gospodarczego. Dalej omówiono podział rozwiniętej gospodarki kapitalistycznej na dwa sektory oraz makroekonomiczne konsekwencje tego podziału.

1 J. K. Galbraith, Monopoly Power and Price Rigidities, ,The Quarterly Journal of Economics” 50, 1936, nr 3 (May). 


\section{PRZEDSIĘBIORSTWO W MYŚLI JOHNA K. GALBRAITHA}

Konkurencja jest jednym z podstawowych elementów gospodarki rynkowej. Jej warunkiem jest istnienie tak wielkiej liczby przedsiębiorstw w danej branży, że żadne $\mathrm{z}$ nich nie ma wpływu na swoje otoczenie rynkowe i przynależące do niego zmienne ekonomiczne. $\mathrm{W}$ tym, co produkować, zdane jest ono na łaskę konsumenta, a w tym, jak i za ile - na łaskę rynku. To rynek jest mechanizmem koordynacji, który za pomoca informacyjnej roli cen dostarcza bodźce do przeprowadzania określonych zmian. Jest też mechanizmem eliminacji, kiedy do wyznaczonych przez rynek zmian lub ich zakresu przedsiębiorstwo się nie dostosowuje, robi to zbyt wolno lub po prostu nieudolnie. Funkcja eliminująca rynku zapewnia funkcjonowanie na nim tylko tych przedsiębiorstw, które działaja efektywnie, a ich produkcja odpowiada wymaganiom konsumentów. Przedsiębiorstwo zatem jest odbiorca wszelkich informacji płynących z rynku i ich wykonawca. Otoczenie rynkowe jawi się jako bardzo dynamiczne i nieprzewidywalne. Według ekonomii neoklasycznej działanie przedsiębiorstwa właśnie w warunkach niepewności ${ }^{2}$ i ryzyka prowadzi zarówno do efektywności mikroekonomicznej (nieustannie zmieniającym się okolicznościom gospodarowania i konkurencji sprostaja tylko najlepsze przedsiębiorstwa) oraz makroekonomicznej (efektywne przedsiębiorstwa gwarantuja optymalną alokację zasobów w skali całej gospodarki).

Inaczej kwestię konkurencji, rynku i wynikającej $\mathrm{z}$ nich niepewności postrzega John K. Galbraith. Twierdzi on, że najlepsze efekty gospodarcze przynosi działanie w warunkach bezpieczeństwa ekonomicznego. W Społeczeństwie dobrobytu - państwie przemystowym pisze: „Wysoki stopień bezpieczeństwa ekonomicznego jest nieodzowny do maksymalnej produkcji. A wysoki poziom produkcji jest niezbędny dla bezpieczeństwa ekonomicznego" ${ }^{3}$. W pierwszej części powyższego cytatu przemawia Galbraith - orędownik keynesowskiej polityki gospodarczej. Zgodnie z tym stwierdzeniem daleko lepsze efekty gospodarcze osiągane są w gospodarce, w której państwo reaguje na niepożądane zjawiska, takie jak spowolnienie gospodarcze. Podmioty działające $\mathrm{w}$ takich okolicznościach korzystniej oceniają przyszłe zdarzenia, co zgodnie z podejściem keynesowskim w dużym stopniu te zdarzenia determinuje. Jeśli jednak już do spadku koniunktury dojdzie, państwo zareaguje odpowiednią polityką, by ów spadek nie przerodził się w recesję gospodarczą. Tak jak ta część zacytowanego fragmentu odnosi się do sfery makroekonomicznej gospodarowania, tak druga - do sfery mikroekonomicznej. Stosunkowo wysoki poziom produkcji danego przedsiębiorstwa - zdaniem Galbraitha - zapewnia bezpieczeństwo gospodarowania. Zgodnie z tym osiągnięcie odpowiednich rozmiarów przez przedsiębiorstwo umożliwia mu kształtowanie zmiennych

${ }^{2}$ Koncepcji niepewności fundamentalnej poświęcony jest artykuł: S. Dunn, Bounded Rationality Is Not Nundamental Uncertainty: A Post Keynesian Perspective, ,„Journal of Post Keynesian Economics” 23, 2001, nr 4 (Summer), a przedsiębiorstu działającemu w ramach fundamentalnej niepewności artykuł: S. Dunn, Fundamental Uncertainty and the Firm in the Long Run, „Review of Political Economy” 12, $2000, \mathrm{nr} 4$.

${ }^{3}$ J. K. Galbraith, Spoteczeństwo dobrobytu - państwo przemystowe, PIW, Warszawa 1973, s. 91-92. 
rynkowych z otoczenia tego przedsiębiorstwa, odpowiednio do jego wymogów: ,[...] rozwój współczesnego przedsiębiorstwa można zrozumieć tylko jako wszechstronny wysiłek zmierzający do zmniejszenia ryzyka. Bez przesady można powiedzieć, że $\mathrm{w}$ innych kategoriach nie da się tego pojąc" ${ }^{4}$. Powszechnym zatem dążeniem przedsiębiorstw jest chęć ograniczenia ryzyka działalności gospodarczej. Zapewnić to może osiagnnięcie odpowiedniej wielkości, przez co przedsiębiorstwo uzyskuje władzę nad dotyczącymi go zmiennymi rynkowymi. W ten sposób przedsiębiorstwo wypiera rynek, jako uosobienie niepewności i wysokiego ryzyka działania, i zastępuje go planowaniem.

„Działalność planistyczna firmy przemysłowej polega na przewidywaniu działań, których należy dokonać między rozpoczęciem produkcji a jej zakończeniem, oraz na przygotowaniu realizacji tych działań. Polega ona również na przewidywaniu wszelkich nieprzewidzianych sytuacji, zarówno korzystnych, jak niekorzystnych, które moga wyłonić się w toku procesu produkcji, oraz na opracowaniu programu odpowiedniego postępowania w tych sytuacjach. Planowanie w rozumieniu ekonomistów [...] polega na zastapieniu cen i rynku jako mechanizmu określającego produkcję przez arbitralne określenie tego, co ma się produkować i spożywać oraz za jaką cenę" ${ }^{5}$.

Galbraith wymienia trzy sposoby zastępowania rynku przez planowanie ${ }^{6}$ : 1) eliminacja rynku; 2) opanowanie rynku przez sprzedajacych lub kupujacych oraz 3) zawieszenie rynku na czas określony lub nieokreślony w drodze umowy między strona sprzedająca i kupująca ${ }^{7}$. Zdaniem Galbraitha w rozwiniętej gospodarce kapitalistycznej wszystkie trzy sposoby sa szeroko stosowane. Eliminacja rynku postępuje wraz z postępowaniem integracji pionowej lub poziomej przedsiębiorstw. Wówczas nabywanie surowców, półproduktów czy też wykonywanie kolejnych procesów produkcji odbywa się nie za pośrednictwem rynku, ale wewnątrz przedsiębiorstwa, a konkurencja w danej branży jest zdecydowanie ograniczona ${ }^{8}$. Dlatego też rynek wraz ze wzrostem integracji przedsiębiorstw z procesu produkcji jest stopniowo eliminowany. Opanowanie rynku polega na ograniczeniu lub nawet całkowitym odebraniu swobody działania tym, z którymi dane przedsiębiorstwo prowadzi wymianę za pośrednictwem rynku. Rynek zatem nie jest eliminowany, ale przedsiębiorstwo ma tak dalece posunięte możliwości wywierania wpływu na decyzje jego uczestników, że właśnie w ten sposób go opanowuje i minimalizuje ryzyko

${ }^{4}$ J. K. Galbraith, Spoteczeństwo..., s. 88.

${ }^{5}$ Ibidem, s. 158-159.

${ }^{6}$ Stephen Dunn uzupełnia te sposoby o dwa dodatkowe o mniejszym znaczeniu: ignorowanie niepewności - kiedy wystąpienie ewentualnych nieprzewidzianych zdarzeń ma ze względu na swoja niewielką siłę minimalne znaczenie dla wielkiego przedsiębiorstwa, oraz absorbowanie niepewności przez dywersyfikację nabywców jego wyrobów. Zob. idem, John Kenneth Galbraith and the Multinational Corporation, „Challenge” 48, 2005, nr 2 (March/April), s. 94-95.

7 J. K. Galbraith, Spoteczeństwo..., s. 161.

${ }^{8}$ Widać tu tu zbieżność poglądów J. K. Galbraitha i O. Williamsona w kwestii rynku i hierarchii, jako sposobu eliminacji rynku. Galbraith rozpatruje jednak przedsiębiorstwo w kategoriach władzy, a Williamson - w kategorii kosztów transakcyjnych. Szerzej zob. S. P. Dunn, Galbraith, Uncertainty and the Modern Corporation, w: M. Keaney (red.), Economist with a Public Purpose: Essays in Honour of John Kenneth Galbraith, Routledge, Londyn 2001, s. 157-182. 
działania $^{9}$. Z kolei zawieszenie rynku, w sensie wyeliminowania wszelkich nieprzewidzianych zdarzeń, polega na obustronnie negocjowanej umowie, określającej podstawowe warunki wymiany na określony czas. Najczęstszą formą zawieszania działania rynku jest kontrakt ${ }^{10}$.

Nie jest jednak tak, że możliwość kontrolowania otoczenia rynkowego dostępna jest dla wszystkich przedsiębiorstw. To, że chęć ograniczania ryzyka działalności gospodarczej przez przedsiębiorstwa jest dążeniem powszechnym, nie oznacza, że wszystkim przedsiębiorstwom uda się ja zrealizować. Decydującą kwestią jest tu technologia. Jeżeli w danej branży ekonomicznie uzasadnione jest stosowanie wysokich technologii na szeroką skalę, to przedsiębiorstwa z tej branży są naturalnie predestynowane do osiagnnięcia stosunkowo większych rozmiarów. Galbraith wymienia sześć następstw mających ogromny wpływ na funkcjonowanie przedsiębiorstwa, a wynikających $\mathrm{z}$ zastosowania w produkcji technologii i nauki. Są to: 1 ) wydłużenie okresu między podjęciem jakiegoś zadania a jego zakończeniem; 2) konieczność zaangażowania większego kapitału; 3) wielkość nakładów czasu i pieniędzy staje się coraz mniej elastyczna; 4) wymaganie wyspecjalizowanej siły roboczej; 5) ze specjalizacja nieuchronnie łączy się organizacja; 6) z powyższych przesłanek wynika konieczność planowania działalności ${ }^{11}$. Wobec takich zmian, jakie powoduje zastosowanie technologii i nauki w procesie produkcyjnym, ryzyko działalności zdecydowanie rośnie. Przedsiębiorstwo nie może sobie pozwolić na nieograniczone działanie sił rynkowych, takich jak choćby zmienność cen, gustów swoich klientów czy też polityki państwa dotyczącej tej branży. Prowadzenie działalności na taką skalę, przy takim zaangażowaniu kapitału, w warunkach niepewności fundamentalnej oraz ryzyka rynkowego stwarza konieczność przejścia danej firmy od działania opartego na rynku do działania planowego.

Druga kluczowa zmiana, jaka zachodzi wskutek zastosowania technologii $\mathrm{w}$ procesie produkcji na szeroką skalę i osiągnięcia przez firmę znacznych rozmiarów, jest przejście $\mathrm{z}$ indywidualnego zarządzania przedsiębiorstwem, na zarządzanie przez organizację. Nowoczesnej technologii organizacja towarzyszy z konieczności. Technologia wymaga specjalistycznej wiedzy, efektywnego systemu podejmowania decyzji grupowych i zaangażowania stosunkowo wielkiego kapitału ${ }^{12}$. W takim wypadku nie jest możliwe, by zarządzanie i proces decyzyjny w wielkim przedsiębiorstwie był domena jednostki. ,,[...] mózgiem [...] nie jest jednostka, ale cały zespół naukowców, inżynierów i techników, specjalistów od sprzedaży, reklamy i marketingu, ekspertów w dziedzinie stosunków międzyludzkich i informacji prasowej, lobbystów, prawników oraz ludzi posiadających wyspecjalizowaną wiedzę na temat biurokracji [...] i sposobów manipulowania nią, koordynatorów, menedżerów oraz kierowników. To właśnie jest technostruktura. I już nie pojedyncza jednostka, ale technostruktura staje się siłą kierowniczą" ${ }^{13}$. Korporacją, która na szeroką skalę stosuje zaawan-

${ }^{9}$ J. K. Galbraith, Spoteczeństwo..., s. 163.

${ }^{10}$ S. P. Dunn, The Origins of the Galbraithian System: Stephen P. Dunn in Conversation with J. K. Galbraith, ,Journal of Post Keynesian Economics” 24, 2002, nr 3 (Spring), s. 349.

11 J. K. Galbraith, Spoteczeństwo..., s. 150-155.

${ }^{12}$ S. P. Dunn, John Kenneth Galbraith..., s. 92.

${ }^{13}$ J. K. Galbraith, Ekonomia a cele spoteczne, PWN, Warszawa 1979, s. 142. 
sowane technologie, nie może kierować już jednostka. Dochodzi to przekazania zarządzania technostrukturze i odsunięciu od niej właściciela przedsiębiorstwa.

„Oddzielenie własności od kontroli to ostre wyzwanie rzucone założeniu maksymalizacji zysku"14. Zdaniem Galbraitha kierująca korporacja technostruktura realizuje inne cele niż maksymalizacja zysku i maksymalizacja zysku jako cel działania wielkiego przedsiębiorstwa jest nie do utrzymania. Jaki cel zatem realizuje korporacja? Żaden. Korporacja postrzegana jest przez Galbraitha jako organizacja. W związku z tym organizacja sama w sobie nie może realizować żadnego celu. Korporacja w ujęciu Galbraitha jest logiczna kulminacja teorii behawioralnej i biurokratycznej ${ }^{15}$. Przez to cele moga realizować uczestnicy organizacji, a nie same organizacje. Takie cele ma technostruktura.

Podstawowym celem technostruktury jest trwanie, a pierwszym jej warunkiem - zachowanie autonomii $\mathrm{w}$ podejmowaniu decyzji ${ }^{16}$. Sa cztery źródła ingerencji w działania technostruktury: 1) właściciele i wierzyciele, 2) robotnicy (za pośrednictwem związków zawodowych), 3) konsumenci, 4) rząd ${ }^{17}$. Z konieczności zachowania autonomii działania wynika pierwszy cel realizowany przez technostrukturę - cel ochronny; realizacja tego celu wymaga osiagania przynajmniej takiego poziomu zysków, który nie rodzi niebezpieczeństwa ingerencji ze strony akcjonariuszy i nie zmusza do korzystania z zewnętrznego finansowania ${ }^{18}$. „Jeśli tylko minimalny poziom zarobków zapewnia bezpieczeństwo technostruktury, pozostaje wówczas sprawa wyboru celów. Wymogiem najważniejszym jest potrzeba trwania. Jednakże nie ma żadnej watpliwości co do metody, jaką ten cel najczęściej jest realizowany: jest to osiaggnięcie możliwie najwyższej stopy wzrostu korporacji, mierzonej wielkością zbytu"19. Jest to cel pozytywny technostruktury.

Podsumowując, w koncepcji Galbraitha przedsiębiorstwo funkcjonuje w warunkach niepewności i ryzyka wynikających zarówno z natury konkurencji i rynku, jak i z samej natury świata ${ }^{20}$. Podstawowym dążeniem przedsiębiorstwa jest ograniczanie niepewności i ryzyka oraz ewentualnych skutków jego wystąienia przez możliwość wpływania i kształtowania otoczenia gospodarczego. Zdaniem Galbraitha w tych kategoriach postrzegać można powstawanie i wzrost firmy. Niewielu jednak firmom uda się osiągnąc taki rozmiar działalności, by przez zastąpienie mechanizmu rynkowego strukturami firmy kształtować otoczenie rynkowe zgodnie ze swoimi oczekiwaniami i tym samym minimalizować wpływ nieoczekiwanych zdarzeń na swoją działalność. Kluczowym elementem tego rozróżnienia jest możliwość

14 Ibidem, s. 154.

15 J. K. Galbraith, Galbraith and the Theory of the Corporation, „Journal of Post Keynesian Economics" 7, 1984, nr 1 (Fall), s. 51-52.

16 J. K. Galbraith, Spoteczeństwo..., s. 249.

17 J. K. Galbraith, Ekonomia..., s. 159.

18 J. K. Galbraith, Społeczeństwo..., s. 249-250.

19 Ibidem, s. 253.

${ }^{20}$ Niepewność jako istotowa cecha rzeczywistości była podstawą ekonomii Johna M. Keynesa. Wobec współczesnych wydarzeń, szczególnie przyczyn i przebiegu kryzysu gospodarczego, zdaniem Roberta Skidelsky'ego rola niepewności i tym samym dziedzictwo myśli J. M. Keynesa powracają na pierwszy plan. Zob. R. Skidelsky, Keynes. Powrót mistrza, Wydawnictwo Krytyki Politycznej, Warszawa 2012. 
ekonomicznie uzasadnionego zastosowania technologii i tym samym organizacji na szeroką skalę. Przedsiębiorstwa, którym się to powiedzie, przez oddzielenie własności od zarządzania kierowane są przez technostrukturę. Do osiągnięcia celów technostruktury najbardziej zbliża, po pierwsze, osiąganie danego minimalnego poziomu zysków, a po drugie, dążenie do maksymalizacji sprzedaży swoich wyrobów.

Takie pojmowanie przedsiębiorstwa i jego ewolucji we współczesnym świecie przez Galbraitha nie kończy się na teorii firmy per se i ma ono swoje głębokie konsekwencje w całym systemie społeczno-gospodarczym ${ }^{21}$. Konsekwencje gospodarcze powyższej roli i kształtu współczesnego przedsiębiorstwa omówione zostaną w następnej części artykułu.

\section{BIMODALNY OBRAZ ROZWINIETEEJ GOSPODARKI KAPITALISTYCZNEJ}

Jak już zauważono, to zastosowanie technologii i organizacji na szeroka skalę jest przełomem na drodze przedsiębiorstwa do wzrostu. Galbraith wychodzi poza tradycyjne spojrzenie mówiące, że „na początku był rynek”, w kierunku poglądu, że „na początku nie było konieczności szerokiego planowania działalności gospodarczej, ponieważ technologia nie była tak wyszukana" ${ }^{22}$. Obecny stan nauki, techniki i umiejętności organizacyjnych pozwala wielu przedsiębiorstwom na stosowanie ich bardzo szeroko. Właśnie wzdłuż stosowalności technologii i nauki na szeroka skalę biegnie linia podziału dojrzałej gospodarki kapitalistycznej na dwa sektory - sektor rynkowy i sektor planujący. Ten model gospodarki Galbraith nazwał gospodarką bimodalną ${ }^{23}$.

Sektor rynkowy to domena przedsiębiorstw o stosunkowo niewielkich rozmiarach. Wielkość tych firm i co za tym idzie - ich nikła siła oddziaływania na otoczenie rynkowe sa determinowane przez brak uzasadnienia ekonomicznego stosowania techniki i organizacji na szeroką skalę. „Sektor rynkowy, będąc mieszanina monopolu i konkurencji w najogólniejszych zarysach przystaje do modelu neoklasycznego" ${ }^{24}$. W sektorze rynkowym poszczególne przedsiębiorstwo nie ma wpływu na swoje otoczenie rynkowe. Nawet jeśli jakaś firma osiagnie pozycję monopolisty, to jest to jednak zwykle efekt chwilowych „,zaburzeń”. Bariery wejścia na rynek w sektorze rynkowym sa tak niskie, że pozycja monopolisty zostanie w długim okresie zniwelowana pojawieniem się konkurentów na tym rynku. Także kształtowanie się cen, płac i zysków w sektorze rynkowym jest wynikiem działania sił konkurencyjnych.

Obok sektora rynkowego istnieje zdecydowanie mniejsza liczba przedsiębiorstw charakteryzujących się ogromną siłą oddziaływania na otoczenie

${ }^{21}$ Społeczne aspekty myśli Galbraitha, mimo ich trafności, współczesności i kompletności ze względu na temat niniejszego opracowania nie zostana przedstawione.

${ }^{22}$ S. P. Dunn, The Origins of the Galbraithian..., s. 348.

${ }^{23}$ J. K. Galbraith, The Bimodal Image of the Modern Economy: Remarks upon Receipt of the Veblen-Commons Award, ,Journal of Economic Issues” 11, 1977, nr 2 (June), s. 192.

${ }^{24}$ J. K. Galbraith, Ekonomia..., s. 97. 
gospodarcze. Tak jak już zostało zaznaczone wcześniej, wobec wysokiego ryzyka będącego immanentną cechą rynku, wobec niepewności fundamentalnej oraz wzrostu ryzyka wynikającego $\mathrm{z}$ zastosowania technologii na szeroką skalę planowanie działalności przedsiębiorstwa jest koniecznością. Dlatego też, zdaniem Galbraitha, technostruktura, zarządzająca stanowiącymi sektor planujący przedsiębiorstwami, kształtuje wszelkie istotne dla siebie zmienne zgodnie z własnymi oczekiwaniami i celami. Do tych zmiennych, które kontroluje technostruktura, należą: ceny wyrobów, zachowania i preferencje konsumentów, koszty, dostawcy i rząd ${ }^{25}$. Jedyną zmienną, której technostruktura nie może kształtować zgodnie ze swoim oczekiwaniem, jest wysokość płac jej pracowników. Jest to następstwem wyłonienia się w przedsiębiorstwach sektora planującego siły przeciwważnej w postaci związków zawodowych ${ }^{26}$.

Jaka zatem zdaniem Galbraitha politykę cenową stosuje technostruktura? Mimo kontroli, jaką sprawuje na cenami swoich wyrobów, technostruktura nie dąży do maksymalizacji zysków. Technostruktura realizuje swoje cele, a jak już powiedziano wcześniej, do ich realizacji najbardziej przybliża ja maksymalizacja sprzedaży wyrobów firmy. Nie można zatem dążyć do maksymalizacji sprzedaży, ustanawiając taką cenę swoich wyrobów, która miałaby maksymalizować zysk. Cena wyrobów przedsiębiorstwa z sektora planującego będzie zatem niższa, a często dużo niższa, niż cena, jaką by to przedsiębiorstwo uzyskiwało, gdyby technostruktura dążyła do maksymalizacji zysku ${ }^{27}$.

Galbraith zwraca uwagę na spójność polityki cenowej prowadzonej przez technostruktury wszelkich przedsiębiorstw stanowiących sektor planujący. $\mathrm{W}$ jego koncepcji konkurencja cenowa pomiędzy przedsiębiorstwami z tego sektora, dlatego że przeszkadza $\mathrm{w}$ osiągnięciu celów technostruktury, jest wykluczona. Dopuszczalna jest jedynie konkurencja na płaszczyźnie jakości produktów, reklamy czy też technik sprzedaży ${ }^{28}$. Dane przedsiębiorstwo w sektorze planującym przewiduje, co moga zaakceptować inne firmy. W ten sposób ustala cenę ,korzystną” dla wszystkich przedsiębiorstw w sektorze. Nie jest to cena idealna dla wszystkich, ale akceptowalna. Przedsiębiorstwa maja poza tym świadomość, że jest to i tak lepsze rozwiązanie niż rywalizacja ${ }^{29}$.

„Warunki wymiany między dwoma sektorami będą bezwzględnie działać na rzecz faworyzowania tego, który kontroluje własne ceny i koszty, a co za tym idzie - także ceny i koszty w drugim sektorze" ${ }^{30}$. Przedsiębiorstwa z sektora planującego wykorzystuja swoją władzę $\mathrm{w}$ kontaktach z przedsiębiorstwami $\mathrm{z}$ sektora rynkowego. Te ostatnie, funkcjonujac $\mathrm{w}$ ramach rynku i konkurencji, dostarczaja swoje usługi czy wyroby po stosunkowo niskich cenach. Sektor

${ }^{25}$ Ibidem, s. 185. O ile kontrola nad cenami, kosztami i dostawcami sprawowana jest za pomoca kontraktów, o tyle kontrola zachowań i preferencji konsumentów jest sprawowana za pośrednictwem szeroko stosowanego marketingu, a nad rządem - przez współpracę technostruktury z biurokracją państwową oraz narzucenie celów technostruktury państwu (wzrost sprzedaży, który jest celem technostruktury, przyczynia się zdecydowanie do wzrostu gospodarczego, będącego celem rządów poszczególnych państw). Zob. S. Dunn, The Origins of the Galbraithian..., s. 349.

${ }^{26}$ J. K. Galbraith, Ekonomia..., s. 188.

${ }^{27}$ Ibidem, s. 191.

${ }^{28}$ Ibidem, s. 196.

${ }^{29}$ Ibidem, s. 194.

${ }^{30}$ Ibidem, s. 106. 
planujący korzysta z usług i wyrobów przedsiębiorstw z sektora rynkowego w tych dziedzinach, w których ryzyko nabywania danej usługi czy danego wyrobu $\mathrm{z}$ rynku jest akceptowalne. W związku z tym sektorowi planującemu zależy na funkcjonowaniu sektora rynkowego.

\section{MAKROEKONOMICZNE KONSEKWENCJE BIMODALNEGO OBRAZU GOSPODARKI}

Podział gospodarki na dwa sektory, na podstawie opisanej wyżej polityki cenowej stosowanej przez przedsiębiorstwa z sektora planującego oraz specyficznych relacji pomiędzy sektorem planującym a sektorem rynkowym, ma swoje głębokie konsekwencje makroekonomiczne. Pierwszą z nich jest potencjalność wywoływania zjawisk kryzysogennych. W teorii keynesowskiej, której Galbraith był zwolennikiem, takim czynnikiem jest wyższa wartość oszczędności od inwestycji. Źródłem tego zjawiska, zdaniem Galbraitha, jest sektor planujący. W przedsiębiorstwach stanowiących sektor planujący decyzje inwestycyjne podejmuje technostruktura. Ponieważ jest to waskkie grono i decyduje ono o ogromnym kapitale, zwiększa się ryzyko niezrównania inwestycji z oszczędnościami w całej gospodarce. Dodatkowo sektor planujący jest - zdaniem Galbraitha - źródłem nierówności dochodowych w gospodarce. Koszty pracy $\mathrm{w}$ sektorze planującym sa poza kontrola technostruktury. Związki zawodowe wywierają nacisk w kierunku zwiększania płac pracowników. Na realizację celów technostruktury nie ma to wpływu, dlatego że wzrost kosztów siły roboczej i spowodowany tym spadek zysków technostruktura rekompensuje sobie natychmiast podniesieniem cen swoich wyrobów, które kontroluje. $\mathrm{Ma}$ zatem możliwość całkowitego przerzucenia wzrostów kosztów płac na konsumentów, a sektor planujący charakteryzuje stały ruch cen i płac w górę. Działanie nowoczesnych związków zawodowych w sektorze planującym, możliwość przerzucania wzrostu kosztów na konsumentów, wykorzystywanie sektora rynkowego we wzajemnych relacjach przez sektor planujący oraz koncentracja pracowników o najlepszych kwalifikacjach w sektorze planującym to immanentne cechy gospodarki bimodalnej generujące wzrost nierówności dochodowych ${ }^{31}$. Nierówny podział dochodów sprawia, że gorzej zarabiające gospodarstwa domowe wydatkują prawie cały dochód, który otrzymuja, podczas gdy grupy społeczne zarabiające zdecydowanie więcej, wydatkują mniejsza jego część. Z tego właśnie powodu powstawać może część nadmiernych oszczędności. Sektor rynkowy, składający się z dużej liczby niemających wpływu na otoczenie rynkowe przedsiębiorstw, rozdysponowuje dochody bardziej równomiernie, co eliminuje źródło powstawania potencjalnych nadmiernych oszczędności.

Jeżeli już nadwyżka oszczędności nad inwestycjami powstanie, to zgodnie z podejściem keynesowskim spadnie popyt. Sektor rynkowy posiada jednak wbudowane mechanizmy samoregulujące. Ponieważ poszczególne przedsię-

31 J. K. Galbraith, Ekonomia..., s. 311-313. 
biorstwa nie maja wpływu na ceny swoich wyrobów, ceny te na skutek spadku popytu także spadną. W dalszej kolejności dojdzie do spadku płac pracowników sektora rynkowego, produkcja jednak nie spadnie, a bezrobocie nie wzrośnie. W sektorze tym równowaga zostanie zatem przywrócona przy niższym poziomie cen, ale do spadku produkcji i wzrostu bezrobocia nie dojdzie $^{32}$. Jeżeli natomiast spadek popytu dotknie przedsiębiorstwa $\mathrm{z}$ sektora planującego, powyższy mechanizm dostosowawczy nie zadziała. Wynika to przede wszystkim z kontroli cen sprawowanej przez technostrukturę danego przedsiębiorstwa. Spadek popytu nie doprowadzi do spadku cen. Nie spadna także płace, na których wysokość stale naciskają związki zawodowe. W związku z tym nie pojawi się efekt wzrostu sprzedaży w wyniku spadku cen ani zrównoważenia niższych płac w wyniku wzrostu zatrudnienia. Dlatego też spadek popytu, który prowadzi głównie do spadku produkcji i spadku zatrudnienia, niekorzystnie wpływa na cele ochronne i pozytywne technostruktury. Proces ten jednak będzie trwał dopóty, dopóki nacisk na obniżanie się zysków nie wywrze na oszczędności wpływu większego niż ten niezbędny do przywrócenia równowagi ${ }^{33}$.

„Wraz z powstaniem sektora planującego gospodarka zaczęła być trwale podatna na niestabilność zniżkową, czyli recesję. $\mathrm{Z}$ tej samej przyczyny stała się organicznie podatna na inflację"34. O tym, że immanentną cechą gospodarki rynkowej jest możliwość wystąpienia nadwyżki oszczędności nad inwestycjami, a przez to niedostatecznego popytu i dalej recesji gospodarczej, pisał John M. Keynes ${ }^{35}$. Jednakże jednym z pierwszych ekonomistów, jak wskazuje Stephen Dunn, którzy dostrzegli niebezpieczeństwo wystapienia inflacji wskutek stosowania polityki keynesowskiej, był Galbraith ${ }^{36}$. Sam Galbraith pisze, że ówcześni ekonomiści przedstawiali różne przyczyny niestabilności zniżkowej (recesji) i niestabilności zwyżkowej (inflacji). Źródła i zalecenia polityki gospodarczej wobec niestabilności zniżkowej opisał Keynes w Ogólnej teorii. W ciągu dziesięciolecia poglądy Keynesa stały się, jak pisze Galbraith, „,niemal nową ortodoksja”. Pogląd, że gospodarka jest podatna na niestabilność zwyżkowa, nie uzyskał jednak podobnej akceptacji. Było to spowodowane zdaniem Galbraitha tym, że wnioski i zalecenia wobec polityki gospodarczej, jakie płynęły z Ogólnej teorii, można było łatwiej pogodzić z głównym zasadami ekonomii neoklasycznej. „Idee neoklasyczne nie ucierpiały na tym w żaden sposób. Z tego punktu widzenia Rewolucja Keynesowska była maleńką rewolucją" ${ }^{37}$.

„,...] podatność gospodarki na recesję i na inflację ma te same przyczyny powstanie sektora planującego oraz związane $\mathrm{z}$ tym pojawienie się nowoczesnych związków zawodowych" ${ }^{38}$. Zdaniem Galbraitha presja związków

32 Ibidem, s. 281-282.

33 Ibidem, s. 283-284.

${ }^{34}$ Ibidem, s. 289.

35 J. M. Keynes, Ogólna teoria zatrudnienia, procentu i pieniadza, WN PWN, Warszawa 2011.

${ }^{36}$ D. Colander, Galbraith and the Theory of Price Control, ,Journal of Post Keynesian Economics” 7, 1984, nr 1 (Fall), s. 33; S. Dunn, The Origins of the Galbraithian..., s. 360.

37 J. K. Galbraith, Ekonomia..., s. 294-295.

${ }^{38}$ Ibidem, s. 294. 
zawodowych na płace oraz możliwość przeniesienia kosztów wzrostu płac w przedsiębiorstwach z sektora planującego na konsumentów to główne źródło inflacji. Do tego dochodzi nieskuteczność zgodnych z ekonomią ortodoksyjna środków walki z inflacja, ponieważ zakładają one funkcjonowanie przedsiębiorstw w otoczeniu konkurencyjnym i rynkowym.

Wymienia się trzy metody zmniejszania popytu w celu ograniczania inflacji. Sa to: 1) zmniejszanie wydatków publicznych, 2) zmniejszanie wydatków prywatnych finansowanych z kredytu oraz 3 ) podnoszenie podatków ${ }^{39}$. Zmniejszanie wydatków publicznych, którym państwo oddziałuje na zmniejszenie popytu i zatrzymanie wzrostu cen, zdaniem Galbraitha, dotyczy najczęściej usług cywilnych w sektorze publicznym i w sektorze rynkowym. Ograniczenie wydatków dotyczy głównie opieki społecznej, budownictwa, usług miejskich czy też oświaty. Wydatki publiczne, które dotyczą sektora planującego, są zwykle zmniejszane w nieporównanie mniejszym stopniu. Drugi sposób oddziaływania na popyt $\mathrm{w}$ celu powstrzymania wzrostu cen na sektor planujący także nie działa. Technostruktura, chcąc osiągnąc cele ochronne, w tym zachowanie autonomii swojego działania, musi być niezależna od zewnętrznych źródeł finansowania. W związku z tym większość wydatków, jakie przedsiębiorstwo $\mathrm{z}$ sektora planującego ponosi, finansowanych jest z zysków zatrzymanych. Oddziaływanie stopa procentowa na koszt kredytu w minimalnym stopniu wpływa zatem na wielkie korporacje. W dużo większym jednak polityka ta oddziałuje na sektor rynkowy, w którym zyski zatrzymane przedsiębiorstw sa zdecydowanie niewielkie. Wówczas wzrost stopy procentowej przekłada się tylko na utrudniony i droższy dostęp do finansowania działalności w sektorze rynkowym. Także i trzeci instrument ograniczania popytu - podnoszenie podatków oddziałuje w dużo większym stopniu na sektor rynkowy niż na sektor planujący. Przedsiębiorstwa z tego drugiego sektora wzrost podatków zrekompensują sobie wyższymi cenami swoich wyrobów, skoro ceny te moga kontrolować. Takiej możliwości nie mają przedsiębiorstwa z sektora rynkowego ${ }^{40}$.

Zdaniem Galbraitha bimodalny obraz gospodarki tłumaczy nie tylko zjawisko inflacji jako konsekwencji keynesowskiej polityki gospodarczej, lecz także zjawisko jednoczesnego występowania inflacji i bezrobocia ${ }^{41}$. Redukcja inflacji za pomoca polityki fiskalnej i monetarnej w warunkach funkcjonowania gospodarki bimodalnej nie musi, zdaniem Galbraitha, doprowadzić do spadku cen. Dlatego, że przedsiębiorstwa $\mathrm{z}$ sektora rynkowego są uzależnione od zewnętrznych źródeł finansowania, są też bardzo czułe na skutki prowadzenia restrykcyjnej polityki monetarnej. Odbija się to na popycie na produkty sektora rynkowego i na ich cenach. Przedsiębiorstwa z sektora planującego, które sa silnie uniezależnione od finansowania zewnętrznego, nie reaguja na podwyższenie stóp procentowych. Wykorzystuja zyski zatrzymane, a w ostatecz-

\footnotetext{
39 J. K. Galbraith, Ekonomia..., s. 299.

${ }^{40}$ Ibidem, s. 299-302.

${ }^{41}$ Występowanie inflacji i bezrobocia w teorii keynesowskiej było niemożliwe. Lekiem na bezrobocie, zgodnie z zaleceniami krzywej Phillipsa, miała być wyższa inflacja, a by zredukować inflację, trzeba było zaakceptować wyższe bezrobocie. W latach siedemdziesiątych XX w. w Stanach Zjednoczonych wysokie bezrobocie i znacząca inflacja wystąpiły jednocześnie.
} 
ności są „najlepszym klientem” banków. Ponieważ kontrolują ceny swoich produktów, ceny te zostana utrzymane na dotychczasowym poziomie. Efektem tego będzie spadek sprzedaży, a w dalszej kolejności - także produkcji i zatrudnienia. Jeśli bezrobocie nie będzie na tyle dotkliwe, by związki zawodowe odstraszyć od naciskania na wzrost płac, a korporacje od podnoszenia cen, to inflacja może utrzymywać się na wysokim poziomie, a bezrobocie może wzrastać. Jak podkreśla Galbraith, inflacji nie moga zahamować ani polityka fiskalna, ani monetarna, chyba że zaakceptuje się bardzo duże bezrobocie. Alternatywą wobec ograniczania dochodów i cen za pomoca bezrobocia jest uzupełnienie polityki monetarnej i fiskalnej o politykę dochodową i cenową ${ }^{42}$.

\section{ZAKOŃCZENIE}

Z istotności zmian wynikających ze wzrostu znaczenia wielkiej korporacji w gospodarce Galbraith zdał sobie sprawę bardzo szybko. Tym samym uświadomił sobie nieprzystawalność współczesnej mu rzeczywistości gospodarczej do obowiązującej wtedy wizji mikroekonomii Alfreda Marshalla ${ }^{43}$. W latach trzydziestych XX w. Galbraith utrzymywał, że przyczyną Wielkiego Kryzysu były powszechna monopolizacja i ograniczenie produkcji przez korporacje $^{44}$. W 1936 r. ukazała się Ogólna teoria Keynesa i to jego objaśnienie przyczyn kryzysu zostało powszechnie uznane za zgodne z prawdą. Tezy zaproponowane przez Keynesa oznaczały prawdziwy przełom w teorii ekonomii oraz w praktyce gospodarczej. Poza tradycyjna teoria podaży siły roboczej, którą Keynes odrzucił, „rewolucja” w makroekonomii odbyła się jednak bez odejścia od neoklasycznej mikroekonomii ${ }^{45}$. Zdecydowana większość autorów podziela pogląd, że to właśnie z tradycji marshallowskiej pochodzą przyjęte przez Keynesa mikroekonomiczne podstawy ${ }^{46}$. W postaci tzw. syntezy neoklasycznej keynesizm funkcjonował do lat siedemdziesiątych.

Druga połowa lat osiemdziesiąych przyniosła jednak renesans myśli keynesowskiej, a jednym z głównych celów badań naukowych stało się poszukiwanie mikropodstaw keynesowskiej makroekonomii. Wiele $\mathrm{z}$ nich sprowadzało się do poszukiwania uzasadnienia nominalnej sztywności cen i płac w gospodarce. A. Wojtyna wymienia wielu ekonomistów, którzy niezależnie od identyfikacji z którymś z odłamów myśli keynesowskiej zajmowali się wyjaśnieniem przyczyn i konsekwencji sztywności nominalnej cen na rynku. Wielu z nich

42 J. K. Galbraith, The Bimodal Image..., s. 194-196.

${ }^{43} \mathrm{~W}$ swoich wspomnieniach Galbraith pisze, że studiowanie ekonomii zaczynał od dzieł Alfreda Marshalla. Kiedy rzeczywistość do teorii nie przystawała, Galbraith teorię stopniowo modyfikował. Z czasem zauważył: ,Swiat Marshalla jest czymś bardzo solidnym, bez bezrobocia, inflacji czy depresji, w każdym razie nie silnej. Nic więc dziwnego, że wielu z tych, którzy studiowali Marshalla, zauważyło, że dobrze byłoby mieszkać w takim świecie”. J. K. Galbraith, A Life in Our Times: Memoirs, Houghton Mifflin, Boston 1981, s. 28-29.

${ }^{44}$ S. Dunn, The Origins of the Galbraithian..., s. 354.

${ }^{45}$ M. Belka, Wspótczesny keynesizm - ewolucja i gtówne kierunki, „Ekonomista” 1990, nr 4-5, s. 612.

${ }^{46}$ A. Wojtyna, Keynesizm $w$ poszukiwaniu podstaw mikroekonomicznych, „Ekonomista” 1995, nr 1-2, s. 417. 
skłaniało się ku zarzuceniu założenia o konkurencji doskonałej na rzecz postrzegania koordynacji rynkowej w ramach szeroko pojętej konkurencji monopolistycznej. Wymienić tu należy choćby O. Harta, H. D. Dixona i N. Rankina czy N. G. Mankiwa ${ }^{47}$. Wydaje się, że uzasadnione jest wpisanie w ten nurt poszukiwań także dokonań Galbraitha.

Galbraith, wychodząc od fundamentalnej niepewności jako immanentnej cechy rzeczywistości, formułuje koncepcję przedsiębiorstwa, które powstaje i rozwija się tak, aby minimalizować niepewność i ryzyko działalności gospodarczej. Przełomowe znaczenie nadaje Galbraith technologii i organizacji. Jeśli dane przedsiębiorstwo efektywnie i na szeroka skalę zastosuje je w swojej działalności, wchodzi na ścieżkę wzrostu. Odrzucając neoklasyczne pojmowanie firmy jako „czarnej skrzynki”, Galbraith analizuje jej wewnętrzną strukturę i uzasadnia takie, a nie inne zachowania wielkich przedsiębiorstw przemysłowych. W ramach tej analizy prezentuje sposób m.in. kształtowania cen i płac $\mathrm{w}$ danej korporacji i w ramach całego systemu gospodarczego. Następnie wskazuje konsekwencje makroekonomiczne wyłonienia się i funkcjonowania grupy wielkich przedsiębiorstw, nazwanej sektorem planującym. Powstanie i wzrost nierówności dochodowych, utrzymujące się inflacja oraz bezrobocie to makroekonomiczne konsekwencje podziału nowoczesnej gospodarki kapitalistycznej na sektor rynkowy i sektor planujący.

Utrzymana $\mathrm{w}$ duchu instytucjonalno-postkeynesowskim ${ }^{48}$ koncepcja firmy i systemu gospodarczego Galbraitha, zdaje się odpowiadać na te pytania, które postawiła myśl keynesowska u progu swojego odrodzenia. Zejście przez Galbraitha w swoich analizach aż do poziomu przedsiębiorstwa sprawia, że włącza się on do dyskusji o mikropodstawach myśli keynesowskiej. O ich przydatności zdecydować powinna jednak empiryczna weryfikacja tez, które Galbraith stawia.

mgr Pawet Umiński

Uniwersytet Mikotaja Kopernika w Toruniu

puminski@doktorant.umk.pl

\section{JOHN K. GALBRAITH BIMODAL IMAGE OF THE ECONOMY \\ IN THE CONTEXT OF KEYNESIAN PROSPECT OF MARKET ECONOMY FUNCTIONING}

Summary

The paper presents the idea of John K. Galbraith in the context of Keynesian thought. Starting from the concept of the company and its growth determinants, Galbraith notes that the growth of some firms leads to the emergence of the planning sector in the economy, made of a group of corporations that control their economic environment. This economic image has its macroeconomic consequences in the form of price and wage rigidities in certain sectors. Thus, the concept of John K. Galbraith is part of the search for microeconomic foundations of Keynesian thought.

${ }^{47}$ A. Wojtyna, Ewolucja keynesizmu a gtówny nurt ekonomii, WN PWN, Warszawa 2000, s. 208-213.

${ }^{48}$ S. Dunn, The Origins of the Galbraithian..., s. 347. 
Copyright of Journal of Law, Economics and Sociology is the property of Faculty of Law and Administration of Adam Mickiewicz University in Poznan and its content may not be copied or emailed to multiple sites or posted to a listserv without the copyright holder's express written permission. However, users may print, download, or email articles for individual use.

Właścicielem praw autorskich do „Ruchu Prawniczego, Ekonomicznego i Socjologicznego” jest Wydział Prawa i Administracji Uniwersytetu im. Adama Mickiewicza w Poznaniu. Zawartość czasopisma nie może być kopiowana, przesyłana do innych stron internetowych bądź zamieszczana na blogach bez pisemnej zgody wydawcy. Niemniej artykuły można drukować, kopiować lub przesyłać w formie elektronicznej na własny użytek. 